\title{
Effect of Mineral Deposition on Shrimp Litopenaeus vannamei in High Alkaline Water of Pennar River, Andhra Pradesh of Southeast Coast of India
}

\author{
Alagarsamy Sakthivel, Periyasamy Selvakumar and Ayyaru Gopalakrishnan* \\ Centre of Advanced Study in Marine Biology, Faculty of Marine Sciences, Annamalai University, Parangipettai 608 502, Tamilnadu, India
}

\begin{abstract}
The Litopenaeus vannamei is one of the most important economical shell fish in throughout the world. Mineral deposition is a continuous problem in Litopenaeus vannamei culture pond in world wild. The current study to compares the water quality parameters, shrimp growth biomass, and mortality rates during harvest between three ponds. Experimental setup was selected three different ponds (brackish water pond, bore well pond, and bore well resevoir pond) were seeded with the same density of the Litopenaeus vannamei at Pennar River Andhra Pradesh, south India. The primary differences between the ponds were as the water source; one pond was filled from the estuary, estuarine-water was fed to the pond, the second one was taken from bore wells with high alkalinity, and there'd one filled from bore well resevoir pond. Temperature in three ponds was varied and it reached up to $29.6^{\circ} \mathrm{C}$ after 125 days of culture. Dissolved oxygen (DO) levels were varied within the acceptable range although levels in the alkaline pond were as near the lower limit in the last 90 days before harvest. Salinity levels were varied in three ponds, above optimal levels and increased over the 120 days. Alkalinity in the estuarine water was typically $<100 \mathrm{ppm}$ and whereas (275-399 ppm) in the alkaline pond. In the alkaline pond, beginning on $75^{\text {th }}$ day the mineral deposits was observed all parts of shrimp over the body and it's including the eye and the inner gill chambers after harvest, $42 \%$ of the shrimp showed this coating. The initial stages of the mineral deposits on shrimps showed pale yellow colour. Elemental analysis identified the major constituents was present in the sample as Manganese, Sodium, Chlorine, Magnesium, Aluminium, Silica, Iron and Calcium. Survival rates of shrimps in the estuarine-waterfed pond was $92 \%$ with a total pond biomass at harvest was 1.65 tons ha $^{-1}$ compared to survival rates of $79 \%$ in the alkaline pond and a biomass at harvest was 1.020 tons $^{-1} \mathrm{~h}^{-1}$. When quality water may be used, its alkalinity should be monitored and diluted with water from other sources.
\end{abstract}

Keywords: Litopenaeus vannamei; Alkaline pond; Mineral deposition; Elemental analysis

\section{Introduction}

The white leg shrimp, Litopenaeus vannamei is an economically important exotic candidate species being cultured in India with high marketable value and minimum challenges during culture. Gunalan et al. stated that the rapid increase in culture areas since the 2008 facilitated spread and outbreaks of number of pathogens, viruses in particular and later researchers documented infectious diseases are a major constrain to shrimp aquaculture production in many countries [1]. The shrimp culture industry has faced serious losses due to the infectious diseases. Since the mid-nineties of the previous century, shrimp aquaculture in Asia are subjected to many problems such as disease out-breaks, environmental degradation, poor pond soil and water quality and is highly correlated with poor management practices in the pond [2-4].

Gopalakrishnan et al. reported that water quality parameters plays an important role in shrimp culture and various aspects concerning the water quality have been reported [5]. Since a decade, a few shrimp farmers of Tamil Nadu, India have been using saline bore-well water for shrimp culture, and they are able to avoid the outbreak of viral diseases. Aguirre-Guzman and Gatesoupe reported in last decade, the biotechnology industry has developed a number of microbial reparations to improve pond water quality, to enhance shrimp growth and survival, or to decrease shrimp disease [6].

Previously Allen Davis et al. has been suggested that if the salinity is adequate, calcium $(\mathrm{Ca})$, potassium $(\mathrm{K})$ and magnesium $(\mathrm{Mg})$ are the most important ions for shrimp survival. Any of these ions can be limiting, but often a lack of $\mathrm{K}$ is the most important factor affecting shrimp. It should be noted that although high levels of $\mathrm{Ca}$ also seem to be necessary, the ratio of Ca: $\mathrm{K}$, which is about 1:1 in seawater, may also be important. In waters where the $\mathrm{Ca}: \mathrm{K}$ ratio is high, the addition of $\mathrm{K}$ to reduce this ratio has been helpful [7]

Shearer Azevedo et al. and Lupatsch et al. suggest that nutrient and energy deposition, and consequently carcase composition, follow rational patterns. Recognizing the rationality and predictability of patterns of mineral depositions could help explain several phenomena and lead to the development of applications. Patterns of mineral deposition have received little attention in the past level [8-10]. Tchung, Gauquelin, and Victoria, Reliable information of cost mineral deposition in shrimp is very limited. The goal of the current investigation was undertaken to study the incidence of mineral deposition on the shrimps cultured use in the borewell-water-fed farms, brackish water fed farms, as well as bore well resevoir fed farms to find out the growth-stage in which the mineral deposition become conspicuous, and compare the growth, survival, morphological changes, and the elemental composition of the shrimps in brackish water and borewell water fed farms.

*Corresponding author: A Gopalakrishnan, Assistant professor, CAS in Marine Biology, Faculty of Marine Sciences, Annamalai University, Parangipettai, India, Tel: +919443537538; E-mail: aquagopal@gmail.com

Received April 17, 2014; Accepted June 24, 2014; Published July 14, 2014

Citation: Sakthivel A, Selvakumar P, Gopalakrishnan A (2014) Effect of Minera Deposition on Shrimp Litopenaeus vannamei in High Alkaline Water of Pennar River, Andhra Pradesh of Southeast Coast of India. J Aquac Res Development 5: 241 doi:10.4172/2155-9546.1000241

Copyright: (c) 2014 Sakthivel A, et al. This is an open-access article distributed under the terms of the Creative Commons Attribution License, which permits unrestricted use, distribution, and reproduction in any medium, provided the original author and source are credited. 
Citation: Sakthivel A, Selvakumar P, Gopalakrishnan A (2014) Effect of Mineral Deposition on Shrimp Litopenaeus vannamei in High Alkaline Water of Pennar River, Andhra Pradesh of Southeast Coast of India. J Aquac Res Development 5: 241 doi:10.4172/2155-9546.1000241

\section{Materials and Methods}

Three different types of ponds were investigated in this present study as brackish water fed pond (A), Bore well fed pond (B) and Bore well water cum reservoir fed pond $(\mathrm{C})$. The ponds were selected for current study and it's located near by the banks of Pennar River

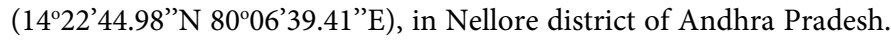
The pond preparation includes drying till cracking, ploughing, adjusting soil $\mathrm{pH}$, bottom levelling, compaction and food and feeding were as same described (Spontaneous WSSV infection in Litopenaeus vannamei grow-out ponds). But in the bore well cum reservoir fed pond the water from the bore well was first stocked in the reservoir pond for $48 \mathrm{~h}$ then pumped in to the grow on pond.

\section{Water quality parameter}

Water quality parameters like temperature, salinity, alkalinity, dissolved oxygen (DO) and $\mathrm{pH}$ were monitored every week throughout the culture period by standard methods of Strickland and Parson. Salinity was measured using a hand refract meter (ATAGO, Japan) and $\mathrm{pH}$ by using a $\mathrm{pH}$ pen, while total alkalinity $\left(\mathrm{HCO}_{3} \mathrm{mg} \mathrm{l}^{-1}\right), \mathrm{Ca}^{2+}, \mathrm{Mg}^{+2}$ and DO (Winkler's method) were determined.

\section{Growth monitoring}

The growths (DOC) of the shrimps were monitored once in a week from $35^{\text {th }}$ days of culture. During the sampling the health and weight gained were monitored.

\section{Shrimp health}

The range of daily growth rate of shrimp was lower in case of pond $\mathrm{B}$, and higher in pond $\mathrm{C}$ and pond $\mathrm{A}$ were as 0.09 to $0.22 \mathrm{~g}, 0.11$ to 0.24 $\mathrm{g}$ and 0.13 to $0.26 \mathrm{~g}$ respectively (Figure 1 ). At the end of the culture period the shrimp average growth was lower in the pond B $(27 \mathrm{~g})$ and higher in bond A (43.2 g) and C (32.4 g) were more or less similar (Figure 2).

\section{Scanning electron microscope (SEM)}

Special attention was paid to the condition of the exoskeleton and to analyse any mineral deposition, which were noted qualitatively. Shrimps exposed obvious mineral deposits were examined using scanning electron microscopy (SEM) (JOEL JSM-5610-LV SEM, at the Central Instrumentation Facility, Annamalai University, India). The shrimps with appreciable mineral deposits were fixed immediately in $2.5 \%$ glutaraldehyde in $0.2 \mathrm{M}$ phosphate buffer at $\mathrm{pH}$ 7.2. The samples were post-fixed with $1 \%$ osmium tetroxide in the same buffer, dehydrated through a graded series of ethanol, and critical-point dried.

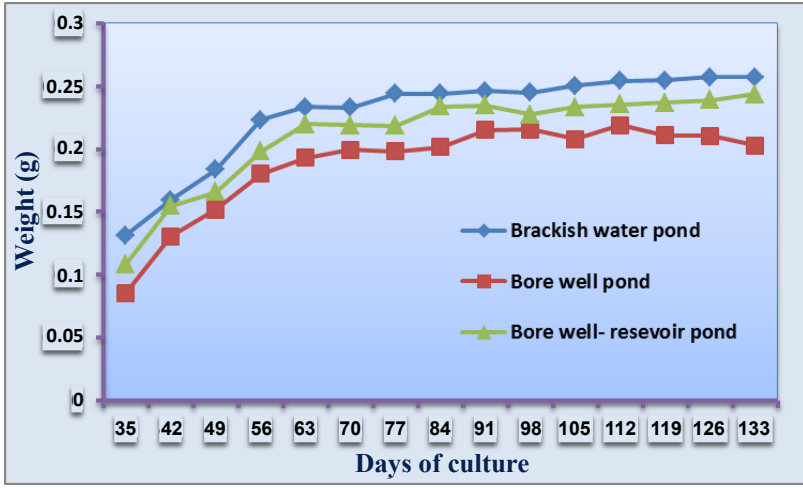

Figure 1: Daily growth rate (DGR) of $L$. vannamei in the pond.

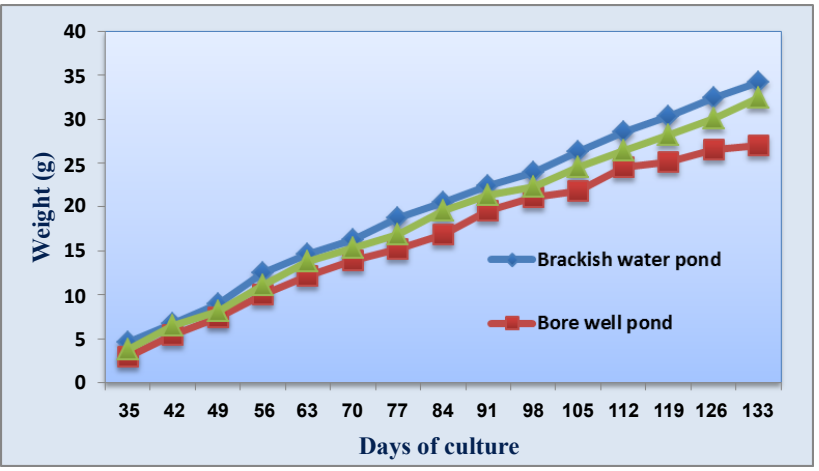

Figure 2: Average body weight (ABW) of L. vannamei in the pond.

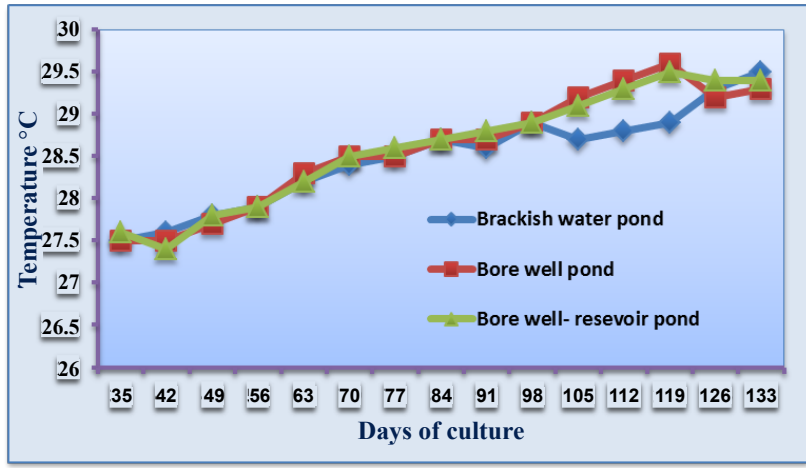

Figure 3: Temperature variation in the $L$. vannamei culture pond.

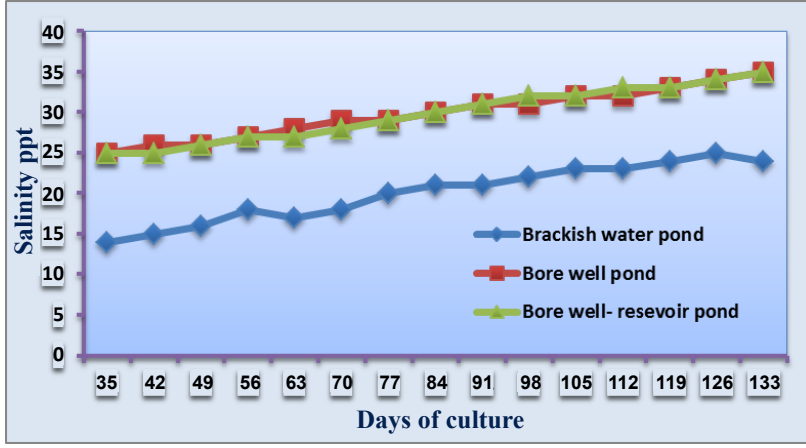

Figure 4: Salinity variation in the L. vannamei culture pond.

Samples were coated with gold and observed under SEM.

\section{Energy dispersive X-ray (EDX)}

To determine the elemental composition of mineral deposits, spectral analysis of anterior-lateral aspect of the shrimp carapace was examined using an elemental energy-dispersive X-ray micro analyser (EDX) (JOEL JSM-5610-LV SEM).

\section{Results}

The temperature among the three ponds was not showed much variation. It was ranged between 27 to $29.5^{\circ} \mathrm{C}, 27.5^{\circ} \mathrm{C}$ to $29.6^{\circ} \mathrm{C}$ and $27.4^{\circ} \mathrm{C}$ to $29.5^{\circ} \mathrm{C}$ in the ponds of $\mathrm{A}, \mathrm{B}$ and $\mathrm{C}$ respectively (Figure 3 ). The range of salinity in the three different ponds were showed in the (Figure 4), lower salinity (14 to $25 \mathrm{ppt}$ ) was observed in the pond A and higher salinity were noted in the pond $\mathrm{B}$ and $\mathrm{C}$ were as 25 to 35 , the same trend 
Citation: Sakthivel A, Selvakumar P, Gopalakrishnan A (2014) Effect of Mineral Deposition on Shrimp Litopenaeus vannamei in High Alkaline Water of Pennar River, Andhra Pradesh of Southeast Coast of India. J Aquac Res Development 5: 241 doi:10.4172/2155-9546.1000241

was observed for $\mathrm{pH}$ also, the minimum was recorded as 7.5 to 7.97 in pond $\mathrm{A}$ and the maximum was recorded in pond $\mathrm{B}$ and $\mathrm{C}$ were as 7.72 to 8.13 and 7.73 to 8.1 respectively (Figure 5). The DO level was almost same in all the three ponds were as 2.4 to $4.6 \mathrm{ml} / 1$ in pond $\mathrm{A}, 2.2$ to 4.4 $\mathrm{ml} / \mathrm{l}$ in the pond $\mathrm{B}$ and 3.1 to $4.5 \mathrm{ml} / \mathrm{l}$ in the pond C (Figure 6).

The alkalinity in all the three different ponds were shown in the (Figure 7) the minimum alkalinity values were observed in pond A, followed by bond $\mathrm{C}$ and in pond $\mathrm{B}$ were 120 to $152 \mathrm{ppm}, 127$ to $174 \mathrm{ppm} 276$ to $399 \mathrm{ppm}$ respectively (Figure 7). In case of $\mathrm{Ca}^{2+}$ the minimum was recorded in the pond $\mathrm{A}$ and pond $\mathrm{C}$ were 275 to 339 ppm and 284-358 ppm respectively and the maximum was observed in the pond B were 367 to $449 \mathrm{ppm}$ (Figure 8). In the case of $\mathrm{Mg}^{+}$the minimum range was recorded in the pond $\mathrm{B}$ were 452 to $603 \mathrm{ppm}$ and maximum was observed in the pond $\mathrm{A}$ and $\mathrm{C}$ were 347 to $819 \mathrm{ppm}$ and 378 to 732 ppm respectively (Figure 9).

The mineral deposition was not observed in the culture ponds until

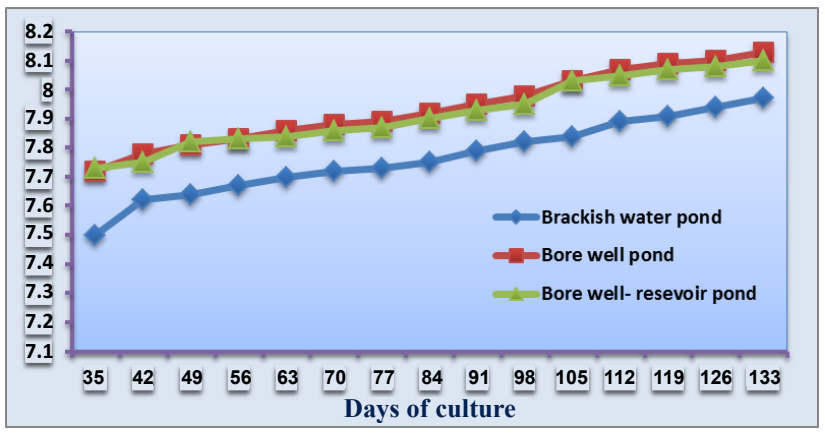

Figure 5: $\mathrm{pH}$ variation in the $L$. vannamei culture pond.

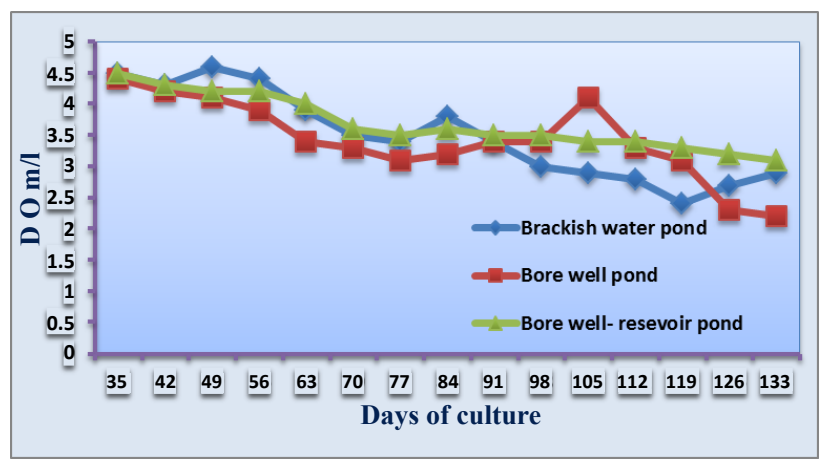

Figure 6: Dissolved oxygen variation in the L. vannamei culture pond.

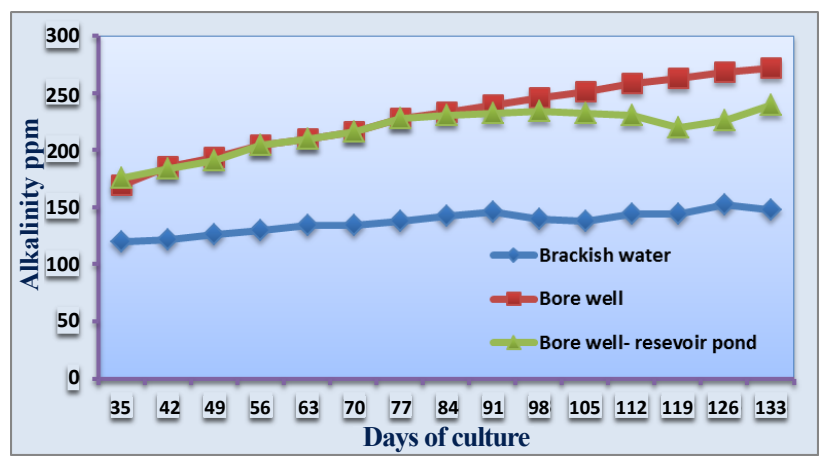

Figure 7: Alkalinity variation in the $L$. vannamei culture pond.

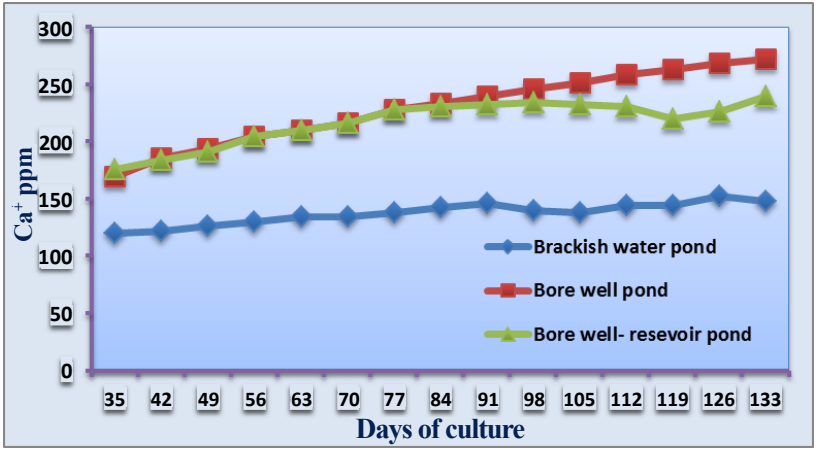

Figure 8: Calcium $\left(\mathrm{Ca}^{+}\right)$variation in the $L$. vannamei culture pond.

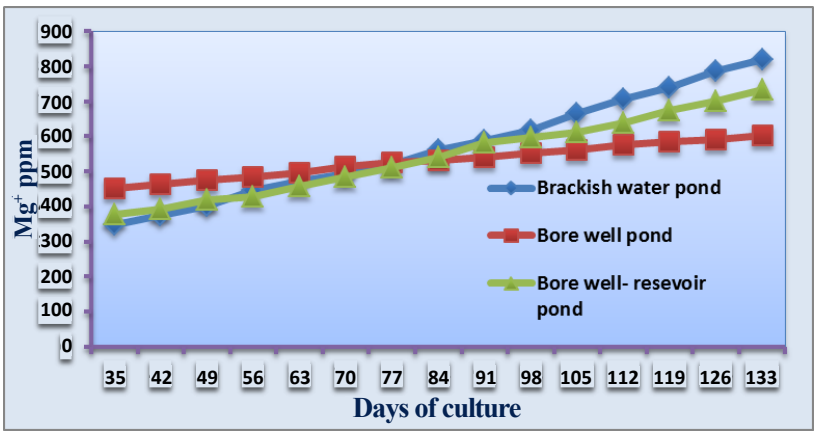

Figure 9: Magnesium $\left(\mathrm{Mg}^{+}\right)$variation in the L. vannamei culture pond.

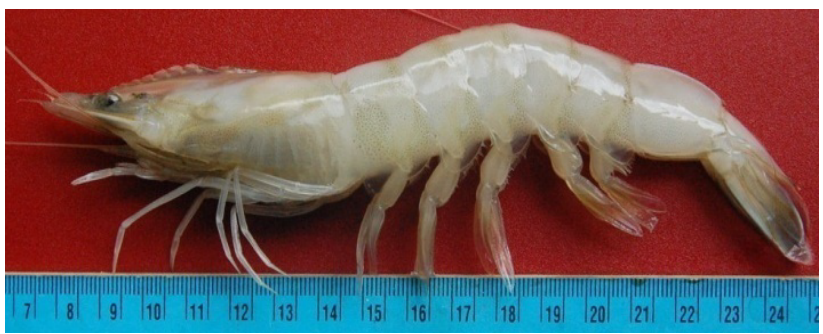

Figure 10: Normal L. vannamei.

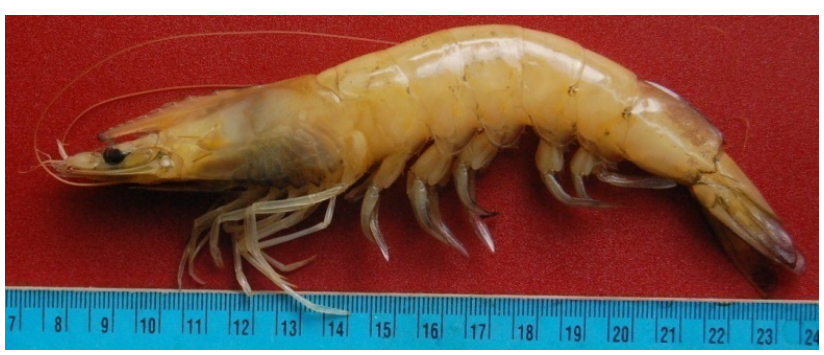

Figure 11: Mineral deposition initial stage of the L. Vannamei.

$70 \mathrm{mg} / \mathrm{L}$, DOC (Figure 10), after $77 \mathrm{mg} / \mathrm{L}$, DOC the mineral deposition fond on the exoskeleton of the shrimps in the pond $\mathrm{B}$, while none of the shrimps in the pond $\mathrm{A}$ and $\mathrm{C}$ had deposit. The initial stages of the mineral deposits shrimps showing in pale yellow in colour (Figure 11). The mineral deposits were clearly seen on all body parts immediately after the shrimp exposed to air, even in the naked eye (Figure 12).

Stereo microscope images of mineral deposition on the antenna and in the antennular plate (Figures 13 and 14), The SEM image of 
Citation: Sakthivel A, Selvakumar P, Gopalakrishnan A (2014) Effect of Mineral Deposition on Shrimp Litopenaeus vannamei in High Alkaline Water of Pennar River, Andhra Pradesh of Southeast Coast of India. J Aquac Res Development 5: 241 doi:10.4172/2155-9546.1000241

Page 4 of 6

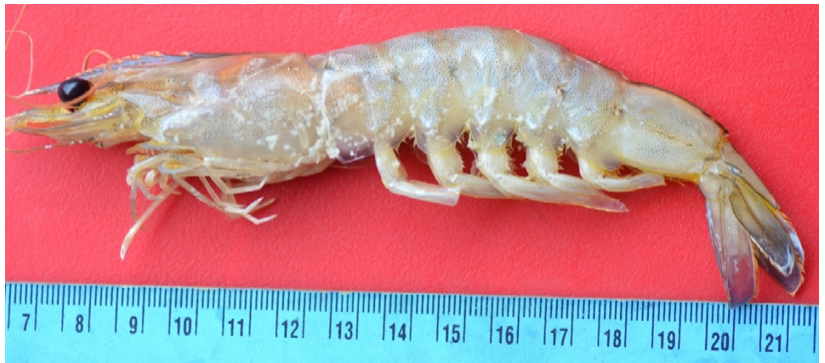

Figure 12: Severe mineral deposited on L. vannamei.

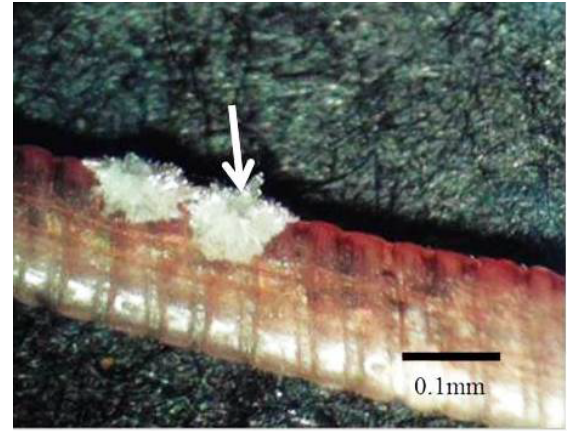

Figure 13: Mineral deposition on the antenna of $L$. vannamei.

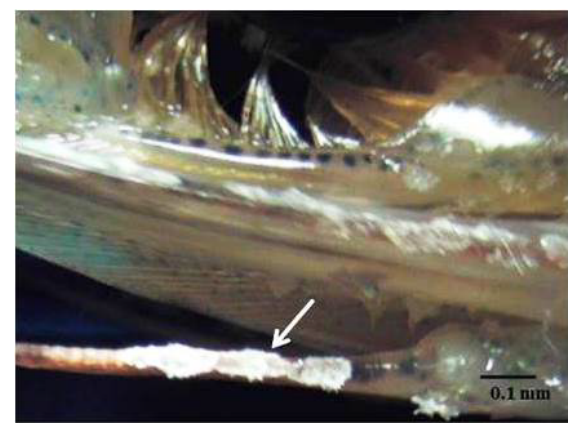

Figure 14: Mineral deposition on the antennular plate of L. vannamei.

the mineral deposits shrimps shows that, it scattered on the carapace during the initial time (Figure 15a), in the higher magnification it shows perforate spot in the surface of the carapace (Figure 15b and 15c) and the single unit of the deposit mineral shows crystal structure (Figure 15d). Further in the end of the culture period the mineral deposits on the almost entire cuticle (Figure 15e), it shows nodule like structure in the high magnification (Figure 15f), even in the higher magnification it shows network of fine crystal structure (Figure 15g). In the close up view of network structure shows stalk like structure in the carapace (Figure 15h).

The elemental composition of mineral values of Manganese, Sodium, Chlorine, Magnesium, Aluminium, Silica, Iron and Calcium (\%) contents in the carapace of mineral deposited shrimp were observed in $3.5 \%, 2.72 \%, 4.54 \%, 1.8 \%, 4.68 \%, 8.49 \%, 1.54 \%$ and $72.73 \%$ (Table 1 ) respectively (Figure 16). These elemental where highly recorded in the three differed ponds brackish water pond, bore well water pond as well as bore well resevoir pond.

\section{Discussion}

The aim of the current investigation was undertaken to study about the incidence of mineral deposition on the shrimp body parts from culture pond and to find out the growth-stage in which the mineral deposition become conspicuous, and compare the growth, morphological changes, and the elemental composition of the shrimps in brackish-water-fed, bore well water fed farms and bore well reservoir
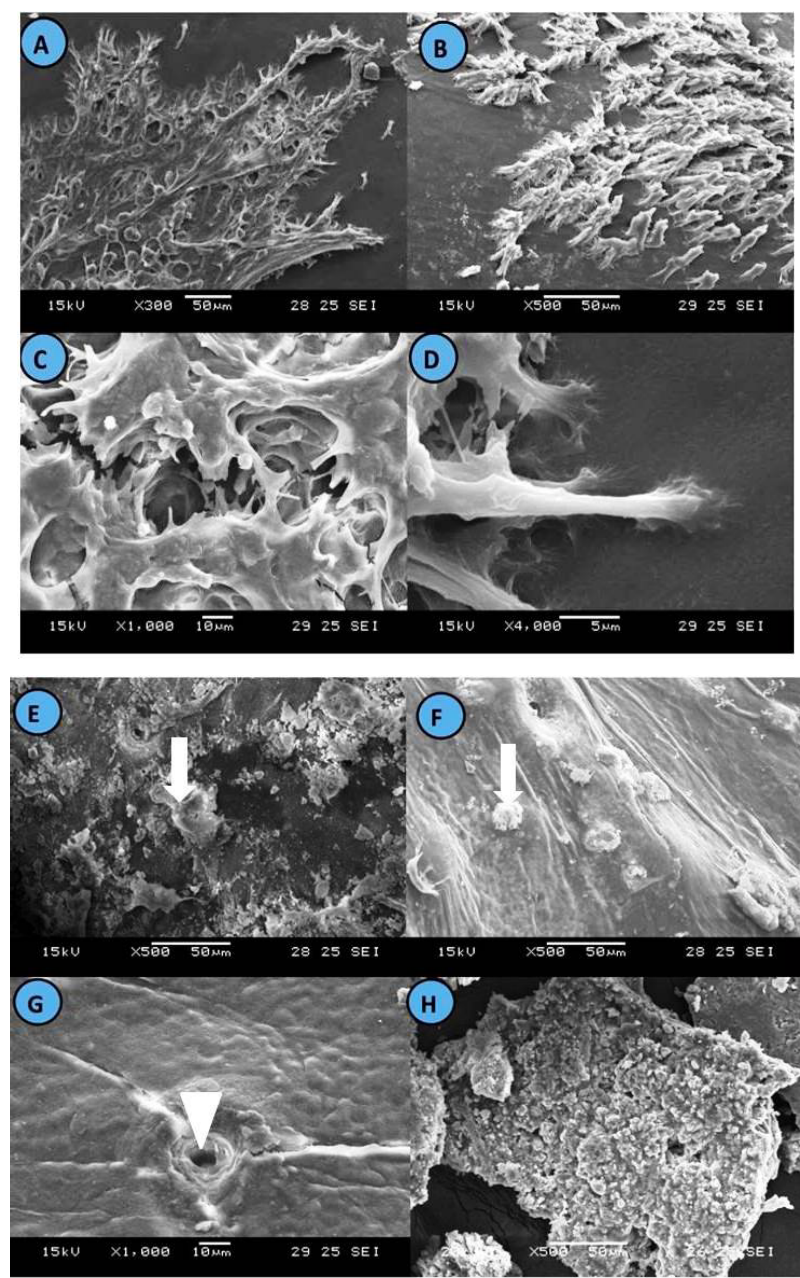

Figure 15: A-D: SEM image showing (A) initial stage of the mineral deposits on carapace, (B) mineral deposits on carapace, (C) fracture through deposit, (D) high magnification view of deposits. E-H: SEM image showing $(E)$ crystal structure, $(F)$ close view of mineral deposition on the carapace, $(G)$ Head arrow shows higher magnification view of depth of the deposition, $(\mathrm{H})$ stalk like structure.

\begin{tabular}{|c|c|}
\hline Element & Weight\% \\
\hline $\mathrm{Na}$ & 2.72 \\
\hline $\mathrm{Mg}$ & 1.80 \\
\hline $\mathrm{Al}$ & 4.68 \\
\hline $\mathrm{Si}$ & 8.49 \\
\hline $\mathrm{Cl}$ & 4.54 \\
\hline $\mathrm{Ca}$ & 72.73 \\
\hline $\mathrm{Mn}$ & 3.50 \\
\hline $\mathrm{Fe}$ & 1.54 \\
\hline Total & 100 \\
\hline
\end{tabular}

Table 1: Elemental composition of the element of deposits on L. vannamei. 


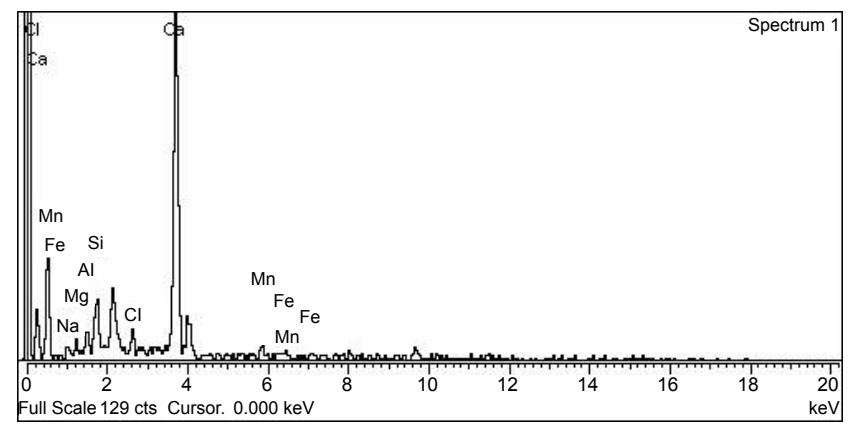

Figure 16: EDX graph of mineral deposits L. vannamei.

pond. Rutledge and Guest have been reported that because the better water quality is essential for good shrimp production, several parameters were monitored daily and many were present within optimal ranges for the shrimp production [11,12]. Maguire and Allen stated that the temperatures play an important role in Shrimp culture [13]. Optimal temperature has been reported between $27-33^{\circ} \mathrm{C}$. But in the case of the present study observed the water temperature $\left(29.6^{\circ} \mathrm{C}\right)$ does not show much variation among the three ponds and also optimum for $L$. vannamei culture. In case of DO the optimal is between 3-5 ppm and lower levels may result in mortality [14,15]. Lee and Wickens, Garcia and Bruna, the other hand to study was demonstrated that the DO level was varied between 2.2 and $4.6 \mathrm{ml} / \mathrm{l}$, almost optimum for L. vannamei culture. It is a euryhaline animal can tolerate the wide range of salinity from 2 to 45 ppt. the result showed the optimum salinity range in the present study.

In the current study, remarkably low alkalinity was recorded in the brackish water creek fed pond and litter higher alkalinity was recorded in the bore well cum reservoir fed pond followed by higher alkalinity was noted in the bore well fed pond. The $\mathrm{Ca}^{2+}$ value was lower in the brackish water pond and in the bore well cum reservoir fed pond and higher was recorded in the bore well fed pond, the minimum $\mathrm{Mg}^{+}$ was recorded in the bore well water fed pond and higher values were recorded in the brackish water and bore well-reservoir fed ponds. Due to this negative correlation of the $\mathrm{Ca}^{2+}$ and $\mathrm{Mg}^{+}$in the bore well fed pond, the $\mathrm{Mg}^{+}$enhance the $\mathrm{Ca}^{2+}$ deposition on the cuticle of the cultured L. vannamei.

Saoud et al. has been reported salinity of $4.0 \mathrm{gL}^{1}$, which is comparable with the salinity utilized by commercial shrimp farms in west Alabama. However, as $\mathrm{K}^{+}$concentration in various waters in west Alabama varies by site, consequently, the $\mathrm{K}^{+}$requirement for $L$. vannamei reared in these well waters varies by site. In addition to salinity of the medium, concentrations of individual elements as well as ratios of various ions necessary for normal osmoregulatory function vary from farm to farm [16]. Magnesium is an essential mineral required by crustaceans for normal growth and development [17]. Magnesium serves as a cofactor in many enzymatic reactions important for normal function, and it is involved in osmoregulation, protein synthesis and growth [18]. Davis et al. who has been reported a lack of dietary $\mathrm{Mg}^{2+}$ has been shown to depress $\mathrm{K}^{+}$concentrations of the carapace in juvenile L. vannamei, indicating a possible interaction between $\mathrm{K}^{+}$and $\mathrm{Mg}^{2+}$ [19]. Similarly, this present study also clearly indicates the $\mathrm{Mg}(1.80 \%)$ was deposited in carapace of L. vannamei.

Due to the higher alkalinity and mineral deposition on shrimps in the bore well fed pond, which contributing lower productivity, the low growth rate, and the low survival rate of $L$. vannamei in the bore well fed pond. The growth rate was higher in brackish water fed and bore well-reservoir fed pond. Chanratchakool stated that the pond alkalinity above $150 \mathrm{ppm}$ coupled with $\mathrm{pH}$ levels above 8.3 lead to the deposition of calcium on the exoskeleton [15]. But in the case of the present study was described the mineral deposited cased the shrimp's growth, biomass and mortality rate of the same ponds. Corbari et al. studied that these shrimp are exposed to mineral laden water and bacteria associated with iron oxide deposits have been described on their branchial chambers [20]. Previously Gopalakrishnan et al. documented that nutrient deposition in shrimp reared under aquaculture conditions is very limited [5]. However when the bore-well water was used, the mineral deposition was noticed on the farm implements like aerators, PVC pipes, electric wires, concrete structures (like sluices) and on the shrimps. Chanratchakool, explained that the mineral deposition made the shrimp's shells rough (rough shell disease), stunted the growth of the shrimp and caused more mortality resulting in less survival rate [15]. Gopalakrishnan et al. documented that SEM images of mineral deposition as a thin layer on the antenna and the inner side of the gill lamellae, multiple layers which fractured vertically while processing shows an undisturbed layer of mineral deposits from the carapace and the ovoid crystal is approximately $8-12 \mathrm{~nm}$ in diameter and is composed of short rods in the P. monodon [21].

EDX analysis of the deposits revealed they are composed primarily of manganese, phosphorus and calcium, with some variation between the carapace and abdomen of the mineral deposit L. vannamei. Similar result was found in mineral deposits $P$. monodon reported by Gopalakrishnan et al. [21]. But in the case of the present study was observed, effect of mineral deposition on shrimp Litopenaeus vannamei in high alkaline water due to use in three different pond brackish water pond, borewell water pond, as well as borewell resevoir pond of Pennar River, Andhra Pradesh of Southeast coast of India.

\section{References}

1. Gunalan B, Soundarapandian, Dinakaran GK (2010) The Effect of Temperature and $\mathrm{pH}$ on WSSV Infection in Cultured Marine Shrimp Penaeus monodon (Fabricius).

2. Lightner DV, Kumula M (1993) Disease of Penaeid Shrimp. In: Handbook of Marinculture: Crustacean Aquaculture. (Ed.:J.P. Mcvey). CRC Press, Boca Raton, FL 393-486.

3. Lightner DV (1996) A Hand Book of Shrimp Pathology and Diagnostic Procedures for Disease of Cultured Penaeid Shrimp. World Aquaculture Society, Bacon Rouge, LD, USA. 305.

4. Subasinghe R (1977) Fish Health and Quarantine. In: FAO Inland Wate Resources and Aquaculture Service, Fishery Resources Division. Review of the State of World Aquaculture, FAO Fisheries Circular No. 886 (Revision 1).

5. Gopalakrishnan A, Rajkumar M, Vasanthan TM, Balasubramanian T, Martin GG (2008) Rough-Shell Disease of the Shrimp Penaeus monodon in The GrowOut Ponds. Seshaiyana, 16, 7-9.

6. Aguirre-Guzman G (1994) Uso De Probiotics Enlace Aquaculture. In: Cruz Suarez, Risque-Marie D, Mendoza-Alfaro R, (Eds.), Proceedings of the Primer Symposium International De Nutrition Technologic De Alimentospara Aquaculture, 9-11 Nov., 1992. Faulted De Cadencies Biologics, Universidad Autonomic De Nuevo Leon, Mexico, 315-321.

7. Allen Davis D, Tzachi M Samocha, Boyd CE (2004) Acclimating Pacific White Shrimp, Litopenaeus vannamei, To Inland, Low-Salinity Waters. Southern Regional Aquaculture Center. 2601

8. Tchung B, (1995) Effete De La Nourrituresur Le Metabolism De La Corvette Penaeus Stylirostris. Memoires De Diploma 'Etudes Approfondies, University Franchise Du Pacifique, Polynésie Francoise 52.

9. Gauquelin F (1996) Effects Du Taux De Protein Salimentairessurla Croissancela Consommationd'oxygene Etlexcrétion Ammoniac Ale De La Corvette Penaeus Stylirostris. Memoires De Stage, Maitres De Sciences Et Techniques, Université De Corse, France, 37. 
Citation: Sakthivel A, Selvakumar P, Gopalakrishnan A (2014) Effect of Mineral Deposition on Shrimp Litopenaeus vannamei in High Alkaline Water of Pennar River, Andhra Pradesh of Southeast Coast of India. J Aquac Res Development 5: 241 doi:10.4172/2155-9546.1000241

Page 6 of 6

10. Victoria LO, (1998) Energiametabolizable Yeficiencian Etade Crecimientobaja Eleffect De Variations Medioambientales En El Cameron. IV Symposium International De Nutricionacuicola 15-18.

11. Rutledge WP, Guest WC (1977) Marine Finfish Culture in Texas. Aquaculture 2: $137-140$.

12. Maguire GB, Allen GL (1992) Effects of Temperature on Growth, Food Consumption and Food Conversion for Penaeus monodon, Penaeus plebejus and Metapenaeus macleay. In: Proceedings of the Aquaculture Nutrition Workshop, Slander Bay. (Eds.: G.L. Allen and W. Deall). 15-17 April, 1991:9799. NSW Fisheries, Brackish Water Fish Culture Research Station, Salamander Bay Australia.

13. Lee DOC, Wickens JF (1992) Crustacean Farming. Blackwell Scientific Publications, Oxford. 154

14. Garcia A, Bruna DE (1999) Transport Limitations of Oxygen in Shrimp Culture Ponds. Aquac. Eng 10: 262-272.

15. Chanratchakool P (2003) Problems in Penaeus monodon Culture in Low Salinity Areas. Aquacul. Asia 8: 54-56.
16. Saoud IP, Davis DA, Rouse DB (2003) Suitability Studies of Inland Well Waters for Litopenaeus vannamei Culture. Aquaculture 217: 373-383.

17. Davis DA, Lawrence AL ((1997) Minerals. In: Crustacean Nutrition. World Aquaculture Society. 6: 50-163.

18. Furriel RPM, Mcnamara JC, Leone FA (2000) Characterization of $\left(\mathrm{Na}^{+}, \mathrm{K}^{+}\right)$ Atpase in Gill Microsome of the Freshwater Shrimp Macrobrachium olfersia. Comp Biochem Physiol 126: 303-315.

19. Davis DA, Lawrence AL, Gatlin DM (1992) Mineral Requirements of Penaeus vannamei A Preliminary Examination of the Dietary Essentiality for Thirteen Minerals. J World Aquacult Soc 23: 8-14.

20. Corbari LM, Zbinden MA, Cambon-Bonavita F, Gaill, Compere P (2008) Bacterial Symbioses and Mineral Deposits in the Bronchial Chamber of the Hydrothermal Vent Shrimp Rimicaris Exoculata: Relationship to Moult Cycle. Aquat. Biol 1: 225-238.

21. Gopalakrishnan A, Rajkumar M, Jun Sun, Martin G, Parida A (2011) Impact of Mineral Deposition on Shrimp, Penaeus monodon in a High Alkaline Water. $J$ Environ Biol 32: 283-287. 